\title{
The harder you run, the longer (and smoother) the road: exercise, muscle and ageing
}

\author{
Graeme L. Close · James E. Brown
}

Received: 29 April 2016/Accepted: 2 May 2016/Published online: 30 May 2016

(C) Springer Science+Business Media Dordrecht 2016

\begin{abstract}
Advances in the understanding of the biological mechanisms that underpin the ageing process have enabled biogerontologists to identify a number of interventions that may potentially impact upon how we age. These interventions include the repurposing of established small molecules including metformin (Anisimov et al. 2015) and rapamycin (Wilkinson et al. 2012; Karunadharma et al. 2015) alongside newer agents including the 'senolytic' drugs (Zhu et al. 2015). These drug-based therapies extensive research into the role of nutrition in ageing has suggested that 'you are what you eat' may be a phrase that rings true in biogerontology. Whilst these advances in understanding have revolutionised how we view the biology of ageing, there is potentially even greater impact to be gained by better understanding the long established role that exercise has in promoting healthy ageing and longevity (van Saase et al. 1990; Booth et al. 2012).

In this special issue some of the latest knowledge about exercise, physical activity, muscle and ageing is
\end{abstract}

\section{G. L. Close}

Research Institute for Sport and Exercise Sciences, Liverpool John Moores University, Liverpool, UK

J. E. Brown $(\square)$

Aston Research Centre for Healthy Ageing \& School of Life and Health Sciences, Aston University, Birmingham, UK

e-mail: j.e.p.brown@aston.ac.uk reviewed. Witard et al. (2016) present the latest, evidence-based recommendations for physical activity and exercise in older adults that may help preserve muscle mass and strength, highlighting the role that different types of exercise must have in any future recommendations for older adults. This is supported by McPhee et al. (2016) who describe how regular physical activity is safe for healthy and for even frail older people and the risks of developing major diseases of ageing are decreased by regularly completing activities ranging from low intensity walking through to more vigorous sports and resistance exercises. Piasecki et al. (2015) take an interesting position on loss of muscle function in ageing, focussing on motor neurons and how remodelling of surviving motor units constitutes the major change in ageing muscles, probably contributing to muscle loss and functional impairments. McLeod et al. (2016) continue the theme of the importance of muscle in ageing as they critique the current literature relating to the maintenance of muscle mass across lifespan, discussing whether maintaining or reducing protein synthesis is the most logical approach to support musculoskeletal function and extension healthy human ageing.

The role of muscle in healthy ageing and agerelated decline is covered in many of the articles presented here. Hughes et al. (2015) present novel data that the ability of testosterone to improve myoblast differentiation and myotube hypertrophy occurs 
predominately via increases in androgen receptor and Akt abundance, identifying a molecular mechanism that may be of importance in regulating muscle mass in older adults. Sharples et al. (2015) further demonstrate that muscle cells have the capability of retaining an elevated methylation state for at least 30 cellular divisions after a single TNF-alpha challenge, identifying an epigenetic memory that may have functional implications. Tomlinson et al. (2015) review some of the functional limitations in muscle performance associated with obesity and in a related review Ikwuobe et al. (2016) propose innovative biomarkers for frailty in type 2 diabetes, including plasma bilirubin, plasma urinary DPP4-positive microparticles and plasma pigment epithelium-derived factor. A review article by Soriano-Arroquia et al. (2016) highlights the role of microRNA in muscle biology, including focus on miR-181a as a regulator of the sirt1 gene expression in skeletal muscle and evidence that miR-181a and its target gene are disrupted in skeletal muscle from old mice. Turner (2016) approaches exercise and ageing from a different perspective, reviewing evidence that exercise might elicit an 'antiimmunosenescence' effect, reporting observations that some forms of exercise are anti-inflammatory, and that repetition over the lifespan is associated with a lower morbidity and mortality from diseases with an immunological and inflammatory aetiology.

Whilst promoting exercise is one approach to increase physical activity and promote health-span, a second approach is to switch the focus onto the reduction of sedentary behaviour. Two review articles shine a light on the role that sedentary behaviour may have in ageing. Wullems et al. (2016) critique the evidence that sedentary behaviour has negative health implications for older adults whilst Perkin et al. (2015) introduce the concept that increased systemic inflammation and reduced protein synthetic responses to protein feeding and muscle contraction might influence the severity of muscle protein loss during periods of total unloading compared with younger individuals.

Finally Professor Janet Lord, Cohen Medal winner at the British Society for Research on Ageing 2015 annual scientific meeting, reviews the impact of ageing upon innate immunity to Streptococcus pneumoniae, as well as age-related changes to the serotypes present in the adult nasopharyngeal tract which could further influence susceptibility to infection (Gonçalves et al. 2015).
It is hoped that the reviews, and original papers, presented within this special issue will be of significant interest to biogerontologists. It is clear from this collection of articles that exercise is a powerful tool in the arsenal of those studying ageing, and that exercise physiology and biogerontology are fields that contain significant overlap. Indeed we postulate that collaborations between biogenentologists and exercise scientists may indeed provide the best blueprint for strategies to attenuate many age-related pathologies. As research increasingly elucidates the precise mechanisms that underlie exercise-induced changes in ageing cells, we can, as a integrative scientific community, ensure that the road we all run continues to gets longer, healthier and happier.

\section{References}

Anisimov VN, Popovich IG, Zabezhinski MA, Egormin PA, Yurova MN, Semenchenko AV, Tyndyk ML, Panchenko AV, Trashkov AP, Vasiliev AG, Khaitsev NV (2015) Sex differences in aging, life span and spontaneous tumorigenesis in $129 / \mathrm{Sv}$ mice neonatally exposed to metformin. Cell Cycle 14(1):46-55

Booth FW, Roberts CK, Laye MJ (2012) Lack of exercise is a major cause of chronic diseases. Compr Physiol 2(2):1143-1211

Gonçalves MT, Mitchell TJ, Lord JM (2015) Immune ageing and susceptibility to Streptococcus pneumoniae. Biogerontology 17(3):449-465. doi:10.1007/s10522-0159614-8

Hughes DC, Stewart CE, Sculthorpe N, Dugdale HF, Yousefian F, Lewis MP, Sharples AP (2015) Testosterone enables growth and hypertrophy in fusion impaired myoblasts that display myotube atrophy: deciphering the role of androgen and IGF-I receptors. Biogerontology 17(3):619-639. doi:10.1007/s10522-015-9621-9

Ikwuobe J, Bellary S, Griffiths HR (2016) Innovative biomarkers for predicting type 2 diabetes mellitus: relevance to dietary management of frailty in older adults. Biogerontology 17(3):511-527. doi:10.1007/s10522-0169634-z

Karunadharma PP, Basisty N, Dai DF, Chiao YA, Quarles EK, Hsieh EJ, Crispin D, Bielas JH, Ericson NG, Beyer RP, MacKay VL, MacCoss MJ, Rabinovitch PS (2015) Subacute calorie restriction and rapamycin discordantly alter mouse liver proteome homeostasis and reverse aging effects. Aging Cell 14(4):547-557

McLeod M, Breen L, Hamilton DL, Philp A (2016) Live strong and prosper: the importance of skeletal muscle strength for healthy ageing. Biogerontology 17(3):497-510. doi:10. 1007/s10522-015-9631-7

McPhee JS, French DP, Jackson D, Nazroo J, Pendleton N, Degens H (2016) Physical activity in older age: 
perspectives for healthy ageing and frailty. Biogerontology 17(3):567-580. doi:10.1007/s10522-016-9641-0

Perkin O, McGuigan P, Thompson D, Stokes K (2015) A reduced activity model: a relevant tool for the study of ageing muscle. Biogerontology 17(3):435-447. doi:10. 1007/s10522-015-9613-9

Piasecki M, Ireland A, Jones DA, McPhee JS (2015) Age-dependent motor unit remodelling in human limb muscles. Biogerontology 17(3):485-496. doi:10.1007/s10522-0159627-3

Sharples AP, Polydorou I, Hughes DC, Owens DJ, Hughes TM, Stewart CE (2015) Skeletal muscle cells possess a 'memory' of acute early life TNF- $\alpha$ exposure: role of epigenetic adaptation. Biogerontology 17(3):603-617. doi:10.1007/ s10522-015-9604-x

Soriano-Arroquia A, House L, Tregilgas L, Canty-Laird E, Goljanek-Whysall K (2016) The functional consequences of age-related changes in microRNA expression in skeletal muscle. Biogerontology 17(3):641-654. doi:10.1007/ s10522-016-9638-8

Tomlinson DJ, Erskine RM, Morse CI, Winwood K, OnambéléPearson G (2015) The impact of obesity on skeletal muscle strength and structure through adolescence to old age. Biogerontology 17(3):467-483. doi:10.1007/s10522-0159626-4

Turner JE (2016) Is immunosenescence influenced by our lifetime "dose" of exercise? Biogerontology 17(3):581-602. doi:10.1007/s10522-016-9642-z van Saase JL, Noteboom WM, Vandenbroucke JP (1990) Longevity of men capable of prolonged vigorous physical exercise: a 32 year follow up of 2259 participants in the Dutch eleven cities ice skating tour. BMJ 301(6766): 1409-1411

Wilkinson JE, Burmeister L, Brooks SV, Chan CC, Friedline S, Harrison DE, Hejtmancik JF, Nadon N, Strong R, Wood LK, Woodward MA, Miller RA (2012) Rapamycin slows aging in mice. Aging Cell 11(4):675-682

Witard OC, McGlory C, Hamilton DL, Phillips SM (2016) Growing older with health and vitality: a nexus of physical activity, exercise and nutrition. Biogerontology 17(3):529-546. doi:10.1007/s10522-016-9637-9

Wullems JA, Verschueren SMP, Degens H, Morse CI, Onambélé GL (2016) A review of the assessment and prevalence of sedentarism in older adults, its physiology/health impact and non-exercise mobility counter-measures. Biogerontology 17(3):547-565. doi:10.1007/s10522-016-9640-1

Zhu Y, Tchkonia T, Fuhrmann-Stroissnigg H, Dai HM, Ling YY, Stout MB, Pirtskhalava T, Giorgadze N, Johnson KO, Giles CB, Wren JD, Niedernhofer LJ, Robbins PD, Kirkland JL (2015) Identification of a novel senolytic agent, navitoclax, targeting the Bcl-2 family of anti-apoptotic factors. Aging Cell 14(4):644-658 